\title{
Od kulturowego pojmowania przestrzeni ku rozważaniom o wieczności. Dyskurs przestrzenny w powieści Brisbane Jewgienija Wodołazkina
}

\section{From the cultural perception of space to reflections on eternity. Spatial discourse in the novel Brisbane by Eugene Vodolazkin}

\begin{abstract}
This article deals with different aspects of space in the text of Eugene Vodolazkin's novel Brisbane as well as in its studies and reception. Successive parts of the research are devoted to lieux de mémoire in autobiographical fiction, cultural understanding of the space of the home and places which traditionally create the image of Kiev and the individual mythology of this city. Space perceived in the way modified by culture is a certain frame in which both the hero of Vodolazkin lives and a receiver reads the novel. It is also an important component of the work's internal structure, the factor responsible for certain genre associations that determine the direction of the reading process. In all these forms of functioning, space is thematically related to the reflection on death. The author concludes that the understanding of space leads to the rejection of the physical future and the affirmation of eternity understood in a religious way, in line with medieval tradition.
\end{abstract}

Keywords: space, cultural memory, eternity, medieval tradition, Vodolazkin

Monika Sidor, Katolicki Uniwersytet Lubelski Jana Pawła II, Lublin - Polska, monyd@kul.lublin.pl, ORCID ID: https://orcid.org/0000-0002-8290-8682

Proza Jewgienija Wodołazkina, choć ciągle jeszcze ilościowo niezbyt imponująca, bo obejmująca pięć powieści i kilka zbiorów opowiadań oraz szkiców, a na pewno mniej obfita niż dokonania naukowe autora, filologa tekstologa, specjalizującego się w badaniach nad staroruskimi zabytkami literackimi, spotyka się z wielkim zainteresowaniem ze strony czytelników i znawców literatury ${ }^{1}$. Wielo-

1 Twórczość Jewgienija Wodołazkina już nieraz była w Polsce przedmiotem naukowego namysłu, którego ukoronowaniem stała się konferencja poświęcona temu twórcy, zatytułowana II Meždunarodnaâ naučnaâ konferenciâ Znakovye imena sovremennoj russkoj literatury: Evgenij Vodolazkin, wraz z następującą po niej publikacją pod redakcją Anny Skotnickiej i Janusza Świeżego (II Meždunarodnaâ naučnaâ konferenciâ, źródło elektroniczne). 
krotne triumfy w zmaganiach o najważniejsze rosyjskie nagrody literackie (Roman Evgeniâ Vodolazkina, źródło elektroniczne; Evgenij Germanovič Vodolazkin, źródło elektroniczne) i ogromna popularność wśród czytelników są związane z indywidualnością pisarza, który - jak się wydaje - wypracował swój własny głos, zestaw tematów i charakterystyczny repertuar środków wyrazu, tworzących niepowtarzalny klimat jego książek. Określenie rosyjski Eco, które na pierwszym etapie twórczości przylgnęło do autora Awiatora (Aвиamop, 2016) (Pisatel' Evgenij Vodolazkin, źródło elektroniczne), dziś może być odczytane w zupełnie nowy sposób. Podobieństwo między dwoma prozaikami wynika nie tylko z zainteresowania kulturą średniowiecza i językiem jako narzędziem komunikacji literackiej, umiejętności osadzenia atrakcyjnej opowieści na tle znanych faktów kulturowych, erudycji, subtelnego humoru czy zręczności w godzeniu sfery popularnej i wysokiej, ale i z niezwykłej zdolności do zwracania uwagi na najważniejsze pytania współczesnego człowieka, uwikłanego w przeróżnego rodzaju sytuacje, kody, konwencje i komplementarne sposoby rozumienia świata. Przy tym ciężar gatunkowy owych pytań skorelowany jest z dość przystępną formą literacką, wciągającą fabułą i wysublimowanym stylem. Nie inaczej jest z powieścią, która stanowi obiekt obecnych badań, Brisbane (Брисбен), wydaną w końcu roku 2018 (Roman v tri oktavy, źródło elektroniczne). Tytuł książki, będący zarazem nazwą realnego australijskiego miasta na zachodnim brzegu najmłodszego kontynentu i trzeciej co do wielkości aglomeracji Oceanii, nie odsyła wcale do miejsca akcji utworu Wodołazkina, co więcej, funkcjonuje jedynie na poziomie fantazji i pragnień. Ten intrygujący fakt skłania interpretatora do zastanowienia się nad rolą realnych i wyobrażonych miejsc w kształtowaniu sensu utworu².

Badacze twórczości Wodołazkina podkreślają skłonność pisarza do pewnych układów motywów, które obecne są niemal we wszystkich jego tekstach literackich, będąc swego rodzaju znakiem rozpoznawczym autora Laura (Лавp, 2012), łatwo zauważalnym nawet w powierzchownym oglądzie (Gorbenko 94). Należą do nich niewątpliwie motywy unoszenia się w przestrzeni, lotu, przemijania, przenikania czasów, poszukiwań samoidentyfikacji, grzechu, przebaczenia oraz wieczności (Boârkina, źródło elektroniczne). Wyznaczają one pewne stałe kierunki refleksji pisarza, odsyłające z reguły do tzw. wiecznych pytań: o istotę czasu, powody ludzkiej od niego zależności, granice egzystencji i substancję wieczności. Właśnie wieczność będzie stanowiła główny problem podejmowanej tutaj refleksji, jednak materiałem do rozważań będą zjawiska innego typu, bo przynależące

${ }^{2}$ Ciekawe, że w kampanii promocyjnej książki wykorzystano ideę, aby lokować powieść w gatunku artystycznego przewodnika (Pât' pričin pročitat' „Brisben”, źródło elektroniczne). Według tego przewrotnego przyporządkowania brak realnych opisów miasta Brisbane jest jedynym możliwym powodem, dla którego książki nie warto czytać. 
do wymiaru przestrzennego, sugerowanego w tytule utworu. Zamierzam bowiem udowodnić tezę, że Wodołazkin łączy sfery przestrzeni i czasu dla wyrażenia ważnych refleksji o wieczności, ukazując przy tym schemat światopoglądowy charakterystyczny dla kultury średniowiecznej. W świecie wykreowanym przez pisarza wypadnie zwrócić uwagę na podmiot poddający namysłowi swoje doświadczenia spacjalne oraz przyczyny, okoliczności i efekty owych doznań. W analizach poruszone będą zagadnienia historii osobistej, subiektywizmu doświadczenia, tożsamości, pamięci, identyfikacji kulturowej czy kulturowego nacechowania przestrzeni, które wyznaczają dość szeroki zakres wykorzystanych narzędzi analitycznych, bo sięgnąć należy do badań spod znaku autobiografizmu, antropologii kulturowej, geopoetyki, poetyki doświadczenia i klasycznego podejścia strukturalnego, poszukując w nich sposobów na objaśnienie zastosowanej przez Wodołazkina strategii opisu i odczuwania wieczności, w których pierwszoplanową rolę odgrywa przestrzeń. Analiza ta łączy więc przeciwieństwa, podobnie jak dzisiejsze różne propozycje geopoetyckie prowadzące do przeorientowania procedur badawczych (Rybicka 59).

Warto zacząc od struktury utworu, zbudowanego na zasadzie kompilacji dwóch odrębnych gatunkowo tekstów połączonych wspólną problematyką. Obydwa są rodzajem opowieści o życiu pewnej osoby, Gleba Janowskiego, światowej sławy wirtuoza gitary i pieśniarza. Pierwszy napisany jest w czasie teraźniejszym w pierwszej osobie liczby pojedynczej i mógłby być przykładem literatury dokumentu osobistego, w tym wypadku dziennika, drugi zaś to zapis przeszłości zrealizowany za pomocą trzeciej osoby liczby pojedynczej i można go nazwać po prostu biografią. Powieść naśladuje więc formę dokumentu, w którym jedna płaszczyzna opowiadania uzupełnia i uwierzytelnia płaszczyznę drugą. Dodatkowo interpretację komplikuje fakt, że cała ukazana tu historia wyraźnie osadzona jest na materiale autobiograficznym, częściowo wykorzystanym już w innych tekstach Wodołazkina. Powstaje w ten sposób wielopoziomowy system odniesień do form prozy autobiograficznej, który w obecnych badaniach wypada zawęzić do świata przedstawionego.

Już na początku utworu, poprzez dobór postaci i miejsca akcji oraz stylizację gatunkową, pisarz naprowadza odbiorcę na trop średniowiecza i na czytanie w kluczu kulturowym lub geopoetyckim (por. Madejski 11-12, 15-16). Stara Ruś oraz jej dziedzictwo cywilizacyjne stanowi bowiem dla bohatera kulturową ramę niemal wszystkich rozważań, poczynając od odniesień do Kijowa, jako historycznej stolicy i miejsca akcji najistotniejszych zabytków staroruskich, które przecież - podobnie jak biografia i pamiętnik Janowskiego - ilustrowały dzieje i rozwój tożsamości pewnego podmiotu, a kończąc na lokalizacji raju. Odniesieniem do kultury staroruskiej jest także oczywiście imię głównego bohatera, przywołujące kontekst opowieści o pierwszych prawosławnych męczennikach, otwierające 
pole dla porównania Janowskiego do średniowiecznego ofiarnika, niewolnego od grzechów, lecz dostępującego przebaczenia. Wodołazkin koduje wydarzenia fabularne według znanych schematów kulturowych, opierających się na zestawie przekonań i wyobrażeń kolektywnych, które można określić jako ramy społeczne ukierunkowujące percepcję i pamięć (Erll 35). W układach zdarzeń i epizodów, w symbolach i obrazach użytych przez Wodołazkina można rozpoznać elementy charakteryzujące pamięć kulturową w rozumieniu Jana Assmanna (Assmann 2013: 37) i według tego samego kulturowego wzorca kształtowana jest w powieści przestrzeń.

Niezwykle ciekawe perspektywy interpretacyjne związane są także z postacią biografa głównego bohatera. Jest nim Nestor, pisarz, którego pseudonim odwołuje się wprost do staroruskiego dziejopisa. Powieść lat minionych stanowi zaś jakby prawzorzec utworu współczesnego Nestora, naznacza kulturowo wszelkie narracje historyczne dotyczące Kijowa (por. Konończuk 9), a także w jakiś sposób uzasadnia koncyliacyjne podejście Gleba do palących kwestii narodowościowych. Przez odwołanie do średniowiecznego zabytku Wodołazkin przenosi problemy i rozważania tożsamościowe bohatera na tło kultury średniowiecznej, na średniowieczny model rozumienia świata sub specie aeternitatis (Vodolazkin 2017: 366-368). Powieściowy Nestor nie jest typem historyka, który stara się być przezroczystym medium odtwarzającym ,jak było" (Topolski 23). Jest pisarzem, siłą rzeczy nakładającym na wydarzenia swoją matrycę, ale także spadkobiercą staroruskiego kronikarza, nieświadomie powracającym do swoich kulturowych korzeni. Przedłużenie problemu dziedzictwa Rusi stanowi kwestia identyfikacji kulturowej bohatera, którego nazwisko w jasny sposób nawiązuje do postaci Mikołaja Gogola, wywołując całe pasmo następnych skojarzeń na temat kulturowych, geograficznych, a wreszcie politycznych zależności Rosji i Ukrainy.

Wracając do kwestii cech gatunkowych powieści, które motywują badania nad odniesieniami przestrzennymi, trzeba zauważyć, że obydwa składowe teksty, fikcyjny dziennik i fikcyjna biografia, w postaci oderwanych fragmentów opatrzonych datami - dokładniejszymi, jeśli chodzi o wydarzenia bieżące, i ogólnymi, rocznymi, jeśli mowa o przeszłości - mieszają się w nierównych proporcjach w kompozycji utworu, tworząc dwie komplementarne fabuły, które jednak przy bliższym oglądzie układają się w uporządkowany zapis losów Gleba Janowskiego, rozgrywający się na dwóch płaszczyznach: przeszłości i teraźniejszości. Badacze, sugerując się jednym z zagadnień podjętych w książce, skłonni są nazywać tę cechę utworu polifonią (Kaplan, źródło elektroniczne). Nie podważając prawomocności użycia tego terminu, należy zwrócić uwagę na cel wykorzystania przez Wodołazkina owego zabiegu. Odnosi się on bowiem nie tylko do sposobu konstrukcji fabuły i podejmowanych tematów, ale także do preferowanego przez pisarza trybu oglądu świata. Nie tylko implikowani autorzy dwóch składowych 
tekstów, ale wszyscy bohaterowie utworu i cały ukazany kosmos wypowiadają się jednocześnie za pomocą właściwego sobie języka, zlewając się w narrację o tym samym, o wieczności. Warto tu odnotować specyficzną mowę przestrzeni, traktowanej na sposób kulturowy. Już na pierwszym wspomnianym etapie badania, strukturalnym, można dostrzec jakąś niekonsekwencję czy też dysproporcję akcentującą rolę płaszczyzny przestrzennej w opisie, gdyż dziennikowe wpisy Gleba zawierają precyzyjną informację nie tylko o czasie, lecz także o miejscu zapisu. Fragmenty biograficzne orientowane są zaś tylko za pomocą daty rocznej. Ten autorski zabieg ma, jak się wydaje, odzwierciedlić naturalne różnice między narracjami o przeszłości i teraźniejszości, uwarunkowane ograniczeniami ludzkiej pamięci, ale jednocześnie ukazuje ważną właściwość losów bohatera, która jak dowodzą antropologowie - określać może także jego osobowość (Rybicka 51). Jest on mianowicie człowiekiem zmieniającym często miejsce pobytu, nieustannie podróżującym obywatelem świata, łatwo akceptującym i oswajającym nową przestrzeń, a przebieg jego życia można przedstawić w postaci listy odwiedzonych przez niego miejsc. Takie podejście jest zgodne $\mathrm{z}$ utrwalonym w kulturze wyobrażeniem życia jako drogi, które w powieści Wodołazkina wybrzmiewa, nieco prowokacyjnie, jako wspomnienie z zasobów pamięci komunikacyjnej (Assmann 2015: 36), dotyczące nietypowej odmiany wyrazu droga.

Русские формы - путь, пути, пути, путь, путем, пути - сопоставлялись там с украинскими: путь, путі, путі, путь, путтю, путі. Главное отличие: в украинском путь - она. Грамматический женский род. Однажды Глеб спросил отца, как так получилось, что путь - она. Тому що наша путь, ответил Федор, вона як жінка, м'яка та лагідна, в той час як російський путь - жорсткий, для життя непередбачений. Саме тому у нас і не може бути спільної путі (Vodolazkin 2019: 81).

Wodołazkin naprowadza czytelnika na pewne kierunki refleksji przez wykorzystanie odpowiednich terminów, rekwizytów czy tematów w warstwie narracyjnej. W tym wypadku wspomnienie o wyrazie droga wywołuje zadumę nie tylko nad różnicami leksyklanymi między językiem ukraińskim i rosyjskim, ale sugeruje rozmyślanie o szerokim kulturowym kontekście tego pojęcia. Na podstawie kulturowej trwałości relacji życia i drogi Małgorzata Czermińska postawiła tezę, że narracje biograficzne przedstawiające ukształtowane kulturowo fazy w przebiegu życia jednostki mają specyficzne odniesienia przestrzenne, które zasługują na odrębne badania (Czermińska 13). Nie zatrzymując się na zagadnieniu prawdziwości narracji omawianej powieści, lecz na jej strukturalnym podobieństwie do dokumentu, warto przywołać ustalenia badaczki:

Szukanie spacjalnych kontekstów kolejnych etapów czasowego przebiegu życia nie jest kaprysem ani uzurpacją, ale sięgnięciem do bardzo starej tradycji. Chodzi o intuicję tkwiącą głęboko u najdawniejszych podstaw myślenia o ludzkiej egzystencji w naszym kręgu kulturowym, intu- 
icję utrwaloną w wyobrażeniu życia jako drogi, niesioną przez potoczny w polszczyźnie zwrot „droga życiowa” i w łacińskiej nazwie podstawowej formy życiorysu curriculum vitae, czyli bieg ,życia” (Czermińska 13).

Czermińska dostrzega potrzebę mówienia o „miejscach autobiograficznych”, które zostały ukształtowane subiektywnie w procesie formowania się tożsamości jednostki pod wpływem indywidualnego doświadczenia i pewnego kulturowego osądu. Polska literaturoznawczyni zwraca więc uwagę na obecność w autobiografiach faz i punktów antropologicznych pozwalających na dostrzeżenie takich modeli przestrzennych, jak miejsce urodzenia, miejsce dzieciństwa dla pierwszej fazy życia, podróż edukacyjna dla młodości czy miejsce stabilnej egzystencji w starości. Czermińska zauważa wariantywność znaczeniową owych miejsc, która jednak nie podważa racji ich wyodrębnienia (Czermińska 29).

W tym sensie pamiętnikarskie fragmenty Brisbane w opisach lokalizacji wyznaczających koleje życia bohatera przypominają pod względem statusu miejsca autobiograficzne w literaturze dokumentu osobistego. Dzieciństwo spędzone w Kijowie oraz podróż inicjacyjna, która w tym wypadku odbywa się dwuetapowo, gdyż pierwszy etap wyznacza wyjazd do Moskwy, podczas którego Gleb odkrywa gorycz odrzucenia miłosnego, a etap drugi to wyjazd na studia do Petersburga (wówczas Leningradu). Już w samym zestawieniu trzech wymienionych miast można upatrywać głęboko symboliczny sens, swoiste odzwierciedlenie przełomowych punktów historii kultury rosyjskiej, a w związanych z nimi doświadczeniach bohatera - zwykle przypisywany owym miejscom charakter. W obydwu fazach życiowych właściwości przestrzeni ukazane są przez pisarza $\mathrm{z}$ wielką pieczołowitością. Jest to zarówno przestrzeń geograficzna, dominująca we fragmentach dziennikowych i manifestująca się przez wyraziste opisy topograficzne, jak i przestrzeń wyobrażona - obrazy osadzone częściowo na cechach realnej przestrzeni, a częściowo na ukształtowanych kulturowo matrycach i osobistych wyobrażeniach.

Motyw drogi ukazuje głęboką korelację czasu i przestrzeni, które - jak twierdzi Yi-Fu Tuan - „koegzystują, zazębiają się i określają w osobistym doświadczeniu”, a „każde działanie powoduje strukturę czasoprzestrzenną” (Tuan 167). Geograf podkreśla, że poczynając od renesansu przestrzeń i czas nabrały subiektywności przez fakt „zorientowania wobec człowieka” (Tuan 158), a efekty tego procesu można zaobserwować w sztuce europejskiej. Dla naszych rozważań ta konstatacja jest ważna o tyle, że większość narracji utworu Wodołazkina wyraża właśnie takie, typowe dla sztuki nowożytnej, podejście do czasu i przestrzeni jako konstruktów akcentujących indywidualne doświadczenie. Przemieszczanie w przestrzeni jest tu ukazywane jako celowe i odzwierciedlające indywidualną historię bohatera. A jednocześnie jako pewnego rodzaju zaburzenie tego układu 
pojawiają się relacje z wydarzeń, które według Yi-Fu Tuana powodują unieważnienie wcześniej wspomnianej relacji. Uczony pisze: „Muzyka może zakłócić świadomość ukierunkowanego czasu i przestrzeni. Rytmiczny dźwięk zsynchronizowany z ruchami ciała osłabia poczucie celowego działania, poruszania się w historycznym czasie i przestrzeni ku celowi" (Tuan 164). W analizowanej powieści wiele razy odnotowane jest właśnie takie doświadczenie zatrzymania czasu i zatarcia tła przestrzennego pod wpływem muzyki: „Беря в руки инструмент, Глеб перемещался туда, где времени нет" (Vodolazkin 2019: 162). Można powiedzieć, że ukazując momenty ekstazy spowodowanej muzyką, Wodołazkin zaburza spójność opisu drogi życiowej bohatera i odwołuje się w bardzo subtelny sposób do innego odczuwania świata, utrwalonego w sztuce średniowiecznej, odzwierciedlającego archaiczne pojmowanie historii, w którym nie zaznacza się jeszcze subiektywizacja odczucia czasu i przestrzeni.

Podobne znaczenie ma, jak się wydaje, wyeksponowanie w powieści twierdzenia, że ,życie to przywykanie do śmierci”. Frazę tę wypowiada pensjonariusz domu opieki, ekscentryczny Frantz-Peter, który w pełni może być postrzegany jako figura współczesnego jurodiwego (Vodolazkin 2019: 391, 279), a przez to jego słowa nabierają wydźwięku profetycznego i wyraźnie lokują odbiorcę w horyzoncie kultury staroruskiej. Wodołazkin wprowadza w ten sposób motyw odwrotności znanego obrazu życia jako drogi, nie przerywając narracji, która tenże obraz ilustruje. Powstaje zatem wrażenie pewnej gry z czytelnikiem, w której szczegółowo objaśniona zostaje jedna koncepcja ludzkiego życia, a jednocześnie przebłyskują wyraziste elementy koncepcji o przeciwnej wymowie, bez wywołania dysonansu. W konsekwencji czytelnik jest przygotowywany na radykalne konkluzje Wodołazkinowskiej prozy, które jednak nie mają charakteru obrazoburczej rewolty, a jedynie ukazują inne, nieoczekiwane konteksty dobrze znanych motywów, opisów i refleksji.

Warto wrócić jeszcze na chwilę do ustaleń Yi-Fu Tuana, który dokonał ważnych rozróżnień w zakresie sposobu przeżywania relacji spacjalnych. Przestrzeń konstruowana na podstawie doświadczeń uwzględniających odmienności kulturowe może być więc mityczna, pragmatyczna i abstrakcyjna (Tuan 29). Jednocześnie badacz akcentuje różnicę między przestrzenią i miejscem: „Przestrzeń przekształca się w miejsce w miarę uzyskiwania określeń i znaczeń" (Tuan 173).

Chociaż w obecnym badaniu bardziej interesuje mnie sposób oddziaływania różnych kulturowych oznaczeń przestrzeni na system poglądów ukazanych w utworze niż sama jej charakterystyka, to jednak trudno zupełnie pominąc tę kwestię, stanowiącą przecież podstawę do pozostałych rozważań. Posługując się wspomnianymi wyżej kategoriami, można w utworze doszukać się mitycznej i pragmatycznej odmiany przestrzeni. Jednak trafniej byłoby powiedzieć, że realna przestrzeń geograficzna ukazana $\mathrm{w}$ tekście ma dwa wymiary: kulturowy, 
zewnętrzny wobec bohatera, i osobisty, stanowiący efekt jego indywidualnych doświadczeń. Przy tym ten drugi wymiar, w którym dopiero można wskazać wspomniane wcześniej odmiany, także nie jest formowany poza kontekstem praktyk kulturowych specyficznej dwujęzycznej i niejednorodnej wspólnoty mieszkańców Kijowa. Jego obraz w książce jest, po pierwsze, naznaczony indywidualnym odczuwaniem ogólnie rozpoznawanych elementów miasta. Po drugie zaś, uwzględnia jego historię i rolę w literaturze ukraińskiej oraz duchowości prawosławnej. Bohater przyjmuje specyficzne nawarstwienie praktyk kulturowych, tradycji literackiej czy duchowej jako konieczne i wzbogaca je własnymi przeżyciami. Słynna rakieta, znana turystom amatorom superszybkich rejsów po Dnieprze z lat 80., fragmenty ludowych pieśni ukraińskich, zwyczaje codzienne kijowian i wspomnienia dziecięcych zabaw zlewają się w obraz miasta, które jest ciągle rozpoznawane jako swoje, mimo że szczegóły jego architektury się zmieniły, podobnie jak dominujący język i nawet państwo, do którego przynależy całe rodzinne terytorium.

Дохожу по Владимирской до Прорезной и поворачиваю в сторону Крещатика. В душе спокойствие. Я - часть ночного города. Провел здесь свое детство, оно служит мне защитой. Иду, невидим для всех, в облаке воспоминаний. Касаюсь ладонью домов, потому что каждый мне знаком: в них я когда-то входил или просто шел мимо. Беседовал с кемто, остановившись, - когда, с кем? Поставив ногу на каменную тумбу. Слова в памяти цепляются не за собеседника - за место. Являешься через десятки лет, а слова здесь, пожалуйста, висят по-прежнему - на домах, на деревьях - как новенькие (Vodolazkin 2019: 295-296).

Można powiedzieć, że w utworze znajdują się odwołania do lieux de mémoire (Boer 225), które tu mają charakter nie tyle narodowy, ile kulturowy i są traktowane przez bohatera bardzo indywidualnie: „Переезжая через Днепр, крещусь на Лавру - всегда здесь крещусь, в каждый приезд” (Vodolazkin 2019: 295). Punktem odniesienia w tej osobistej wersji przestrzeni jest zaś dom rodzinny, który w pełni zasługuje na status ,miejsca”.

Дома многое отвлекало. Дома. Дому. Дом. Единственный, возможно, в его жизни. Потом домов было много - так много, что они потеряли свое домовое качество и стали местом жительства. А с этим связывала пуповина: Дом. Маленький, двухэтажный, стоял на бульваре Шевченко, бывшем Бибиковском (Vodolazkin 2019: 33).

Ważne, że ta nasycona wartościami i znaczeniami przestrzeń domowa, która jak widać - ciągle jest określana częściowo za pomocą koordynat kulturowych, należy do przeszłości. Dalsze opisy bardziej lub mniej przytulnych pomieszczeń mieszkalnych, które zajmował w swoim życiu bohater, nie zyskują już waloru pierwszego domu. Nawet mieszkanie kupione przez żonę Janowskiego w Peters- 
burgu tylko po to, aby przeprowadzić swego rodzaju rekonstrukcję historyczną początków wspólnej znajomości, nie jest przedstawione w tym szczególnym kodzie miejsca intymnego. Trzeba jednak przyznać, że Wodołazkin jest z zasady bardzo precyzyjny we wszystkich omówieniach przestrzeni, zarówno tych dotyczących przeszłości, jak i teraźniejszości. Okazuje się przy tym, że te pierwsze, mimo że trudno je zakwalifikować jako przykłady locus amoenus, w większym stopniu zasługują na miano miejsca intymnego niż komfortowe przestrzenie teraźniejszości.

Oczywiście można tę sytuację przypisać pracy pamięci. Jednak trzeba zauważyć, że w utworze pamięć nie jest środkiem do wywołania nostalgicznego wzruszenia czy tęsknoty za tym, co było, i nie jest skupiona na przeszłości, ale nastawiona na teraźniejszość, bo pomaga bohaterowi odpowiedzieć na najważniejsze pytania dotyczące jego tożsamości i jego przyszłości. Gleb Janowski koncertuje w wielu miastach i ma kilka domów w różnych krajach. Nie można więc powiedzieć, że bohater Wodołazkina zamieszkuje w jakimś miejscu w pełnym znaczeniu tego słowa (Bašlâr 33-34, 95). Pojęcie zamieszkiwania zakłada przecież stałą relację z pewną przestrzenią, zakorzenienie, odpowiedzialność, poczucie wspólnoty wartości z innymi mieszkańcami, wreszcie możliwość marzenia (Bašlâr 26-27). Janowski jest współczesnym nomadą, który wszędzie czuje się jednakowo dobrze (Rybicka 51), a przez to zatraca poczucie przynależności do konkretnego lokum. Pamięć o istotnych miejscach przeszłości ma zaspokoić pragnienie samookreślenia, służyć pomocą w konceptualizacji podmiotowości.

Fragmenty utworu dotyczące przeszłości stanowią, według zamysłu kompozycyjnego, zredagowany przez pisarza Nestora zapis wywiadu rzeki z muzykiem Janowskim i mają przedstawić wirtuoza takim, jakim, ,jest naprawdę". Wydobycie z pamięci wszystkich istotnych w przeszłości miejsc ma być zatem sposobem na powtórne zdefiniowanie artysty w momencie kryzysu osobistego. Chyba najpelniejsze wyjaśnienie jego wątpliwości tożsamościowych pada ze strony ukochanego dziadka i jest utrzymane w duchu antropologii przestrzeni, z jednoczesnym odwołaniem do tradycji kulturowych: „Ти - це ти, Мефодий опять перешел на украинский. Як то співають: людина - як дерево, вона звідси і більше ніде" (Vodolazkin 2019: 399).

Takie spacjalne określenie tożsamości konkretyzuje obraz życia-drogi, ograniczając jego wymiar czasowy jedynie do przeszłości i teraźniejszości. Przestrzeń nie zapewnia bowiem żadnych wskazówek na temat przyszłości, co oczywiście najbardziej interesuje bohatera. W książce Wodołazkina problem przyszłości przejawia się z całą jaskrawością, gdyż motywacją dwugłosowej narracji jest strach bohatera przed rozwojem strasznej choroby, przed niepełnosprawnością i śmiercią, a więc faktycznie przed utratą własnej tożsamości. Ma on nadzieję, że rekonstrukcja jego prawdziwej osobowości w jakiś sposób zapewni jej trwałość. 
Dopiero globalne spojrzenie na obydwa teksty o Janowskim ukazuje, jak ważne dla jego dojrzewania osobowościowego są doświadczenia przestrzenne i w jak wielkim stopniu narracja, która ma być odpowiedzią na strach przed przyszłością, jest opowieścią o miejscach autobiograficznych. W celu określenia problematycznej przyszłości pisarz używa także szczególnego spacjalnego kodu, którego hasłem wywoławczym jest tytułowe miasto Brisbane.

Brisbane od samego początku funkcjonuje w fabule jako wymarzony cel podróży, a więc swego rodzaju topos szczęśliwej przyszłości. Myśl o wyjeździe do Australii motywuje matkę bohatera do zmagań z codziennością. Jest Brisbane niewątpliwie symbolem raju, który zyskał konkretną lokalizację fizyczną, uwzględniając wymogi rzeczywistości sowieckiej, negującej istnienie świata duchowego. A jednocześnie wyobrażenie tego wspaniałego miasta wyraźnie nawiązuje do staroruskich koncepcji geograficznych, harmonijnie łączących rzeczywistość ze sferą sakralną. Raj znajdował się - według przekonań utrwalonych w staroruskich zabytkach literackich - na antypodach dostępnej fizycznie przestrzeni, za granicami znanego świata, ale jego funkcjonowanie miało charakter jak najbardziej realny, mimo braku niekwestionowanych dowodów (por. Lotman 95-96, 103). Wodołazkinowskie Brisbane jest charakteryzowane niemal w ten sam sposób, poprzez melanż faktów i wyobrażeń, zabobonów i wątpliwości. Przykładem tego ciekawego połączenia jest doniesienie prasowe o podważeniu realności Australii (Vodolazkin 2019: 351). Negacja istnienia tego kontynentu znajduje się obok informacji, że Irina Janowska nawiązała korespondencję z jego mieszkańcem, a następnie opuściła własny kraj i już z Brisbane regularnie kontaktuje się telefonicznie z synem. Omawiane miasto funkcjonuje na granicy realności i zmyślenia do ostatnich chwil narracji, bez jednoznacznego określenia jego statusu. Wspomniana wcześniej, rozpoznawalna już na początku powieści, konwencja dokumentalności wskazuje na potrzebę traktowania Brisbane jako prawdziwej lokalizacji fizycznej, a jednak wraz z rozwojem wydarzeń fabularnych realność tego miejsca coraz bardziej się rozmywa i w końcu utworu jest ono traktowane po prostu jako substytut wieczności, miejsce, gdzie żyją ludzie, którzy ukończyli swoją ziemską wędrówkę.

Ważny jest również fakt, że opowieść o bohaterze rozpoczyna się podczas lotu samolotem, w przestworzach, gdzie - według ukazanego w książce szczególnego modelu przestrzennego - ziemskie rozumienie czasu i przestrzeni zostaje unieważnione. Taką deterytorializację i detemporalizację można uznać za przejaw charakterystycznego dla hipernowoczesności stanu przebywania w „nie-miejscu”, według określenia Marca Augégo. „Jeśli jakieś miejsce można zdefiniować jako tożsamościowe i historyczne, to przestrzeń, której nie można zdefiniować ani jako tożsamościowej, ani jako relacyjnej, ani jako historycznej, definiuje nie-miejsce" (Augé 53). Z jednej strony właśnie w takich warunkach bohater wyraźnie potrze- 
buje określić się na nowo, nie według owych zasad, które panują w nie-miejscu, lecz według najbardziej tradycyjnego, można powiedzieć, archaicznego schematu. Z drugiej strony, podróż samolotem, wybijając pasażera ze zwykłego odczuwania czasu i miejsca, oznacza fizyczne unoszenie się, mistyczne zbliżanie się do niebios otwierające możliwość kontaktu ze zmarłymi.

В полете он думал о бабушке. Прижавшись носом к иллюминатору, всматривался в облака. В конце концов он ее увидел. Она брела, сгорбившись, вверх по пологому облаку. Заоблачная жизнь чем-то напоминала обычную: дома, деревья, животные. Всё, включая бабушку, из белого, летучего, влажного. Бабушка шла к большому облачному дому, где eе, по-видимому, ждали (Vodolazkin 2019: 261-262).

Myśl o niebiańskim bytowaniu zmarłych należy do dobrze rozpoznawalnego arsenału najstarszych wierzeń, a jednocześnie akcentuje antropologiczną tendencję uprzestrzennienia wyobrażeń o wieczności. Podtrzymuje ją Wodołazkin, przedstawiając historię swojego bohatera jako „opowieść w miejscach”, której zwieńczeniem ma być przyzwyczajenie się do śmierci i odkrycie wieczności. Zagłębianie się w poznanie przestrzeni jest drogą do pokonania jej ograniczeń, a wtedy ona sama staje się substytutem wieczności.

Potwierdzeniem takiego kierunku interpretacyjnego są dwa istotne elementy utworu: punkt kulminacyjny akcji oraz epilog. Pierwszym jest śmierć Wiery wywołująca zawieszenie zasad przestrzeni fizycznej. Przeżywając tę tragedię, Janowscy mentalnie przenoszą się do małego kalabryjskiego miasteczka, do którego mieli pojechać wraz z przybraną córką. Na wysokim brzegu Scalei doznają oni niemal religijnego olśnienia, w wyniku którego przez chwilę doświadczają istnienia wieczności i poznają, że czas i przestrzeń są tożsame. To moment, w którym z całą wyrazistością zaakcentowany jest wymiar wieczności: przestrzeń realna i wyobrażona mieszają się, a rzeczywiste doświadczenia przechodzą w iluzję. Przypomina to staroruskie odczuwanie przestrzeni i czasu, utrwalone na przykład na ikonach ilustrujących historie świętych, gdzie wszystkie wydarzenia wyeksponowane są jednocześnie, plany się przenikają, a skalę poszczególnych składowych obrazu określa nie czas czy miejsce, lecz znaczenie przedstawionych momentów w wielkiej historii zbawienia.

Podobną kompozycją odznacza się drugi z wymienionych wcześniej elementów, czyli epilog. Ukazane tu oderwane informacje dopiero po odczytaniu w określonym kontekście ujawniają pewną spójność. Okazuje się, że Irina Janowska nie mieszka wcale w Brisbane i nie telefonuje stamtąd do syna w najważniejszych momentach jego życia, lecz od wielu lat nie żyje. Sam wirtuoz zaś zapytany o to, czy dodałby coś do swojej biografii, opowiada o jeszcze jednym doświadczeniu przestrzeni, podobnym do przeżycia z wyobrażonej Scalei, lecz znacznie wcześniejszym, w którym po raz pierwszy zetknął się ze strachem 
przed śmiercią. To dopowiedzenie logicznie zamyka historię odkrywania śmierci i przywykania do niej.

W ten sposób ostatecznie przestrzeń zostaje zdefiniowana jako metafora wieczności, a narracja o życiu Janowskiego urasta do rangi opowieści o sensie egzystencji każdego człowieka. Wieczność jest tu przedstawiona jako realne doświadczenie tych, którzy przywykli do śmierci, a ta dojrzałość otwiera na średniowieczne odczuwanie świata, w którym panuje nieustanna teraźniejszość, a więc wszystkie wydarzenia rozgrywają się zawsze „teraz” i ,tutaj”. Wodołazkin w wypowiedziach metaliterackich twierdzi zresztą, że bliska jest mu właśnie taka, staroruska perspektywa (Vodolazkin 2017: 368).

Przestrzeń ukazana w utworze jest zakodowana według kulturowego wzorca. Wodołazkin filolog obdarza swoich bohaterów typowym doświadczeniem kulturowym, konstruując ich losy na zasadzie intertekstualności, która w tym przypadku nie jest nastawiona na grę estetyczną, lecz wydobywa wieczne problemy, podejmuje refleksję - rzec można - średniowieczną, bo pobrzmiewa w niej dydaktyczny patos literatury staroruskiej z jej opowieściami o starcach, świętych, prawiednikach, męczennikach i jurodiwych. Doprowadza to wręcz do zaprzeczenia podstaw współczesnego wyobrażenia o świecie, opartego na technologii i nauce. Odpowiedzią na lęk bohatera przed nieznaną przyszłością staje się bowiem doświadczenie przestrzeni, dowodzące realności raju i wieczności.

\section{Bibliografia}

II Meždunarodnaâ naučnaâ konferenciâ Znakovye imena sovremennoj russkoj literatury: Evgenij Vodolazkin. Web. 01.12.2020. https://ifw.filg.uj.edu.pl/konferencje/-/journal_content/56_INSTANCE_Ymd6/1717115/139773146.

Assmann, Jan. Pamięć kulturowa. Pismo, zapamiętywanie i polityczna tożsamość w cywilizacjach starożytnych. Przeł. Anna Kryczyńska-Pham. Wstęp i red. Robert Traba. Warszawa, Wydawnictwa Uniwersytetu Warszawskiego, 2015.

Assmann, Jan. „Communicative and cultural memory”. The theoretical foundations of Hungarian 'lieux de mémoire' studies. Red. Pál S. Varga, Karl Katschthaler, Donald E. Morse and Miklós Takács. Debrecen, Debrecen University Press, 2013, s. 36-43.

Augé, Marc. Nie-Miejsca: wprowadzenie do antropologii hipernowoczesności. Przeł. Roman Chymkowski. Przedm. Wojciech J. Burszta. Warszawa, Wydawnictwo PWN, 2011.

Bašlâr, Gaston. Izbrannoe: Poètika prostranstva. Przeł. Mihail Û. Miheev, Nataliâ V. Kislova. Moskva, Rossijskaâ političeskaâ ènciklopediâ (ROSSPÈN), 2004.

Boârkina, Polina. Evgenij Vodolazkin. Brisben. Web. 01.12.2020. https://magazines.gorky.media/ zvezda/2019/3/brisben.html.

den Boer, Pim. „Loci memoriae - Lieux de memoire”. Przeł. Paweł Majewski. Antropologia pamięci. Zagadnienia i wybór tekstów. Red. i wstęp Paweł Majewski, Marcin Napiórkowski. Oprac. Roman Chymkowski i inni. Warszawa, Wydawnictwa Uniwersytetu Warszawskiego, 2018, s. 223-230. 
Czermińska, Małgorzata. „Przestrzenne odniesienia czasowych faz biografii”. Przestrzenie geo(bio) graficzne w literaturze. Red. Elżbieta Konończuk, Elżbieta Sidoruk. Białystok, Wydawnictwo Uniwersytetu w Białymstoku, 2015, s. 11-39.

Erll, Astrid. Kultura pamięci. Wprowadzenie. Przeł. Agata Teperek. Red. i posłowie Magdalena Saryusz-Wolska. Warszawa, Wydawnictwa Uniwersytetu Warszawskiego, 2018.

Evgenij Germanovič Vodolazkin. Web. 01.12.2020. https://bookmix.ru/authors/index.phtml?id=510.

Evgenij Vodolazkin. Sajt, posvâŝennyj tvorčestvu pisatelâ. Web. 01.12.2020. https:// evgenyvodolazkin.ru/.

Gorbenko, Aleksandr, „Voskrešenie i ubijstvo slovom: metamorfozy žiznetvorčestva v proze Evgeniâ Vodolazkina”. Znakovye imena sovremennoj russkoj literatury: Evgenij Vodolazkin: kollektivnaâ monografiâ. Red. Anna Skotnicka, Janusz Świeży. Kraków, Wydawnictwo Uniwersytetu Jagiellońskiego, 2019, s. 83-95.

Kaplan, Vitalij. Žizn' kak prodolženie žizni: v čem smysl novogo romana Vodolazkina „Brisben”?. Web. 01.12.2020. https://foma.ru/zhizn-kak-prodolzhenie-zhizni-v-chem-smyisl-novogo-romana-vodolazkina-brisben.html.

Konończuk, Elżbieta. „Poetyka przestrzeni geograficznej według Kennetha White’a”. Wyobraźnia przestrzenna w perspektywie geopoetyki. Red. Elżbieta Konończuk, Katarzyna Trusewicz, Szymon Trusewicz. Białystok, Wydawnictwo Uniwersytetu w Białymstoku, 2018, s. 9-22.

Lotman, Jurij M. „Dwa teksty semiologiczne: o pojęciu przestrzeni geograficznej w średniowiecznych tekstach staroruskich”. Przeł. Maria Mayenowa. Teksty: teoria literatury, krytyka, interpretacja, 3 (15), 1974, s. 93-113.

Madejski, Jerzy. „Wstęp. Przewodnik, bedeker, poradnik i geoliteratura”. Geoliteratura. Przewodnik, bedeker, poradnik. Red. Jerzy Madejski, Sławomir Iwasiów. Szczecin-Kraków, Universitas, 2019, s. 5-20.

Pât' pričin pročitat' „Brisben” Evgeniâ Vodolazkina i odna pričina ne čitat' ètot roman. Web. 01.12.2020. https://evgenyvodolazkin.ru/3318_pyat-prichin-prochitat-brisben-evgeniyavodolazkina-i-odna-prichina-ne-chitat-etot-roman/.

Pisatel' Evgenij Vodolazkin - ob anonimnyh otzyvah, tehničeskom progresse i besede s Èko. Web. 01.12.2020. https://altapress.ru/afisha/story/ne-nado-moshchnih-obobshcheniy-oni-lzhivipochti-vse-205798.

Roman Evgeniâ Vodolazkina „Brisben” polučil premiû „Kniga goda”. Web. 01.12.2020. https:// www.sobaka.ru/entertainment/books/95859.

Roman v tri oktavy. Galina Ûzefovič - o tom, kak ustroen „Brisben”, samaâ muzykal'naâ kniga Evgeniâ Vodolazkina. Web. 01.12.2020. https://meduza.io/feature/2018/12/08/roman-v-trioktavy.

Rybicka, Elżbieta. Geopoetyka. Przestrzeń i miejsce we współczesnych teoriach i praktykach literackich. Kraków, Universitas, 2014.

Skotnicka, Anna, Janusz Świeży, red. Znakovye imena sovremennoj russkoj literatury: Evgenij Vodolazkin: kollektivnaâ monografiâ. Kraków, Wydawnictwo Uniwersytetu Jagiellońskiego, 2019.

Topolski, Jan. Jak się pisze i rozumie historię. Tajemnice narracji historycznej. Warszawa, Oficyna Wydawnicza Rytm, 1996.

Tuan, Yi-Fu. Przestrzeń i miejsce. Przeł. Agnieszka Morawińska. Wstęp Krzysztof Wojciechowski. Warszawa, Państwowy Instytut Wydawniczy, 1987.

Vodolazkin, Evgenij. „Ob istorii i obŝestve”. Dom i ostrov, ili instrument âzyka. O lûdâh i slovah. Moskva, Izdatel'stvo AST, 2017, s. 366-377.

Vodolazkin, Evgenij. Brisben. Roman. Moskva, Izdatel'stvo AST, 2019. 